\title{
ПЕТРОГРАФИЧЕСКИЙ СОСТАВ ВАЛУННОЙ ФРАКЦИИ ЛЕДНИКОВЫХ ОБРАЗОВАНИЙ В РАЙОНЕ КУЗРЕКА-МОСЕЕВО (ЮГ КОЛЬСКОГО ПОЛУОСТРОВА)
}

\section{Носова О.Ю., Вашков А.А.}

Геологический институт КНЦ РАН, Anamuты, nosova@geoksc.apatity.ru

Изучение вещественного состава является одной из важнейших задач при исследовании ледниковых образований. Полученные таким образом данные служат для определения источников сноса горных пород и, как следствие, путей и направлений движения ледниковых покровов. В работах многих геологов, исследовавших четвертичные отложения Кольского полуострова, приводится обширный материал по изучению петрографического состава валунной и галечной фракций морен $[5,6,7]$. Это позволило установить основные направления движения и структуру ледниковых покровов в Кольском регионе. Однако остался ряд не до конца решённых вопросов относительно взаимодействия ледниковых лопастей, генезиса, возраста и вещественного состава краевых образований региона.

В ходе полевых работ 2017 г. по изучению ледниковых образований района населённых пунктов Кузрека-Мосеево (восточнее полуострова Турий) исследовался петрографический состав валунной, галечной и гравийной фракции тиллов. В настоящей статье представлены результаты изучения состава валунной фракции абляционного тилла.

На поверхности гряд ледникового генезиса проводился сбор валунов размером более $10 \mathrm{~cm} \mathrm{c}$ участка $5 \times 5$ метров. Валуны группировались по породам, из каждой группы отбирались наиболее характерные образцы, из которых впоследствии изготавливались петрографические шлифы. Количество валунов на участках достигало 500-600 штук. По результатам полевых и лабораторных исследований было выделено 14 основных групп пород (табл. 1).

Таблица 1. Петрографический состав проб участков Кузрека (К) и Мосеево (М).

\begin{tabular}{|c|c|c|c|c|c|c|c|}
\hline № & Группы & К, шт. & $\begin{array}{l}\text { M, } \\
\text { Шт. }\end{array}$ & № & Группы & К, шт. & M, шт. \\
\hline 1 & Песчаники & 1 & 288 & 8 & Нефелиновые сиениты & 10 & 9 \\
\hline 2 & Гнейсы & 244 & 130 & 9 & $\begin{array}{l}\text { Щелочные породы (ги- } \\
\text { пабиссальной фации) }\end{array}$ & 2 & 11 \\
\hline 3 & Гранитоиды & 71 & 126 & 10 & Фойдолиты & 1 & 2 \\
\hline 4 & Амфиболиты & 80 & 19 & 11 & Гранофиры & 2 & 1 \\
\hline 5 & Гранулиты & 52 & 18 & 12 & $\begin{array}{l}\text { Долериты, метагаббро- } \\
\text { долериты }\end{array}$ & 4 & 0 \\
\hline 6 & $\begin{array}{l}\text { Породы вулканогенно- } \\
\text { осадочных толщ }\end{array}$ & 49 & 17 & 13 & Метаперидотит & 2 & 0 \\
\hline 7 & $\begin{array}{l}\text { Габброиды / метагаб- } \\
\text { броиды }\end{array}$ & 47 & 12 & 14 & Плагиовебстерит & 1 & 0 \\
\hline
\end{tabular}

Кристаллический фундамент на севере района исследований сложен гнейсами и гранитогнейсами комплекса основания, метаосадочными и метавулканогенными породами кислогубской свиты верхнеархейского стратифицированного комплекса и сергозёрской толщи кольско-беломорского нестратифицированного комплекса, гранитоидами терского комплекса (TerC) (рис. 1). Эти породы прорываются мелкими телами габбро-амфиболитов и метаультрабазитов терского комплекса (TrsC). На северо-западе района расположены крупные массивы гранулитов Лапландского гранулитового пояса. В районе п-ва Турий и севернее архейские породы и гранулиты прорваны крупной многофазной гранитоидной интрузией умбинского комплекса. Данные гранитоиды также слагают вытянутые массивы западнее и восточнее полуострова. Среднерифейские осадочные породы образуют широкие полосы вдоль побережья Белого моря (терская свита) и небольшой участок на юге п-ва Турий (турьинская свита). В пределах Турьего полуострова умбинские гранитоиды и турьинские песчаники прорываются щелочными интрузиями, а вдоль южного побережья полуострова ще- 


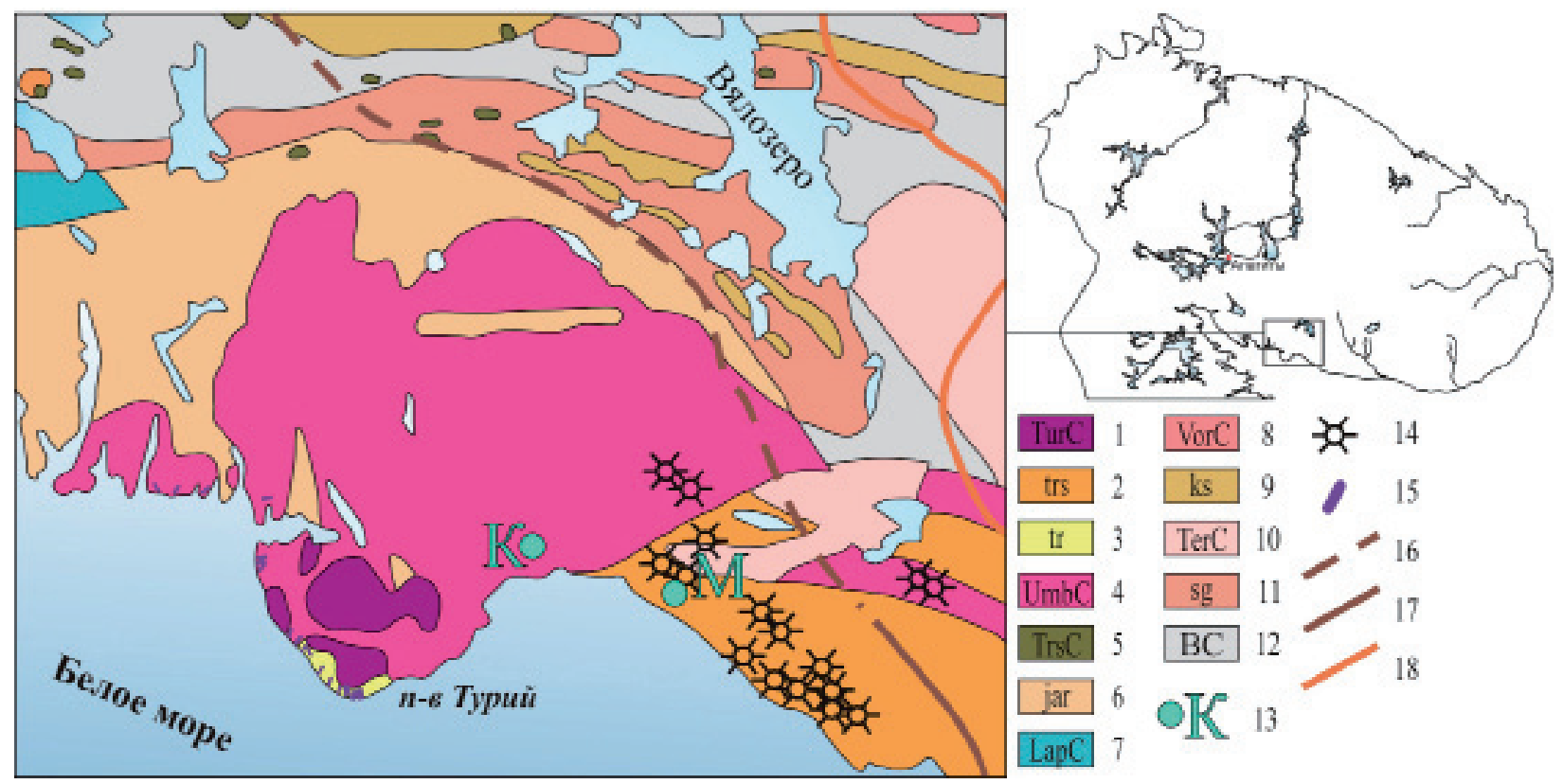

Рис. 1. Геологическая карта района полевых работ [2, 3].

1 - основные, ультраосновные щелочные породы комплекса Турьего мыса; 2 - песчаники, конгломераты, алевролиты терской свиты; 3 - песчаники, конгломераты турьинской свиты; 4 - эндербиты, чарнокиты, порфировидные граниты умбинского комплекса; 5 - габбро-амфиболиты, метаультрабазиты терского комплекса; 6 - кислые гранулиты яуриокской толщи; 7 - средние гранулиты, эндербиты лапландского комплекса; 8 - лейкограниты, гранодиориты вороньинского комплекса; 9 - слюдяные парагнейсы, сланцы, кварциты кислогубской свиты; 10 - плагиограниты, тоналиты терского комплекса; 11 - гнейсы, амфиболиты, кальцифиры серговской толщи; 12 - гнейсы, плагиогранитогнейсы, амфиболиты комплекса основания; 13 - точки отбора проб: К - Кузрека, М - Мосеево; 14 - трубки взрыва; 15 - дайки щелочных пород; 16, 17 - граница стадии оледенения Сальпаусселька 1 (предполагаемая и достоверная); 18 - граница стадии оледенения Невская 1, достоверная.

лочными дайками. В результате вмещающие породы существенно фенитизированы [4]. Также в породах терской свиты и умбинского комплекса встречаются трубки взрыва, сложенные ультраосновными щелочными породами [8].

Четвертичные образования в районе исследований представлены маломощным прерывистым чехлом ледниковых, водно-ледниковых, морских, аллювиальных и болотных образований. Ледниковые отложения формируют цепочки конечно-моренных гряд (рис. 1), построенных складчатым, базальным и абляционным тиллом и водноледниковыми осадками.

Петрографический состав валунной фракции ледниковых образований в районе исследований характеризуется следующими особенностями:

1. Песчаники. В группу входят красноцветные аркозовые песчаники и гравелиты, фенитизированные серые песчаники, бежевый аркозовый песчаник. Данные породы составляют около половины валунов пробы Мосеево, в пробе Кузрека же отмечается лишь единичная находка бежевого песчаника. Источником красноцветных песчаников и гравелитов являются толщи терской свиты, развитой вдоль побережья и на шельфе Белого моря. Фенитизированные песчаники принесены из осадочных толщ Турьего п-ва. Песчаник пробы Кузрека предположительно снесён с Турьего п-ва или шельфа Белого моря.

2. Группу гнейсы составляют плагиогнейсы, плагиогранитогнейсы, биотитовые, амфиболбиотитовые, амфиболовые гнейсы, часто значительно мигматизированные, а также мигматитграниты. Они широко развиты на юге Кольского полуострова и севере Карелии и представляют породы архейского основания. Сюда также отнесены единичные находки двуслюдяных гнейсов, фенитизированных гнейсов, бластомилонитов и метасоматитов по плагиогнейсам. Фенитизированные гнейсы могут быть принесены из толщ гнейсов основания, контактирующих с Хибинским, Лово- 
зёрским массивами и небольшими щелочными интрузиями (Салмагорский массив, Лесная варака, Озёрная варака и др.). Породы группы гнейсы доминируют в пробе Кузрека и вторые по распростанённости в пробе Мосеево. Фениты по гнейсам обнаружены в обеих пробах.

3. В группу гранитоиды объединены порфировидные плагиомикроклиновые граниты, роговообманковые гранодиориты (в том числе эндербиты, чарнокиты и гнейсы по ним), среднезернистые биотитовые граниты. Данные породы в основном принадлежат умбинскому комплексу [1], но часть их могла быть также принесена из гранитоидных массивов терского, лицко-арагубского и вороньинского комплексов с северо-запада. В пробе Мосеево встречены фениты по гранитоидам (7 шт.), которые развиты на п-ве Турий. В точке Мосеево валунов гранитов больше, чем в пробе Кузрека. Это объясняется тем, что ледник эродировал бо́льшую площадь местных пород умбинского комплекса.

4. Амфиболиты представлены массивными, полосчатыми и сланцеватыми разностями, состоящими из роговой обманки и плагиоклаза. Характерно присутствие диопсида, граната. Основными источниками данных пород служат крупные амфиболитовые массивы Кандалакшско-Колвицкой зоны, а также амфиболиты комплекса основания. Немногочисленные сланцеватые разности амфиболитов, кроме того, могли быть принесены из вулканогенно-осадочных толщ верхнеархейского стратифицированного комплекса [8] и сергозерской толщи. Часть амфиболитов могла быть принесена из мелких интрузий терского комплекса района работ.

5. Группа гранулиты в основном представлена кислыми гранулитами (силлиманиткордиерит-биотитовые гранатсодержащие гнейсы), отдельными образцами средних (гранат-кварцполевошпатовых) и основных (гранат-клинопироксеновых) гранулитов. Вышеперечисленные породы развиты на северо-западе района работ.

6. Породы вулканогенно-осадочныхх толщ представлены биотитовыми мелкозернистыми парагнейсами и сланцами, амфибол-диопсидовыми гнейсами, мусковитовыми гнейсами с кианитом, амфиболитами по основным эффузивным породам, единичными образцами плагиоклаз-хлоритсерицитового сланца с гранатом, хлорит-актинолитового амфиболита, трахита, роговообманкового сланца с реликтами фенокристаллов плагиоклаза. Данные породы принадлежат толщам стратифицированного комплекса верхнего архея (кислогубской и др. свитам) и частично сергозёрской толще кольско-беломорского нестратифицированного комплекса [8].

7. В группу габброидов/метагабброидов входят нориты, габбро, анортозиты и их изменённые аналоги. Изменённые породы представлены метагаббро с реликтовой офитовой структурой, слоистыми милонитами по габбро-анортозитам, серицитизированными анортозитами. Источником данных пород могут быть массивы Кандалакшско-Колвицкой зоны, Главного хребта и Имандровского лополита. Часть массивных габброидов могла быть принесена из массивов основных пород Мончегорского района. Источником массивных метагаббро также могли послужить мелкие, но широко развитые на северо-западе от участка работ тела габбро-амфиболитов терского комплекса.

8. Нефелиновые сиениты представлены в основном фойяитами и единичным эвдиалитовым луявритом. Источник данных пород - Хибинский и Ловозёрский (?) щелочные массивы.

9. Щелочные породы (гипабиссальной фащии) представлены нефелинитами, мончикитами, авгититом, фурчитом, эвдиалитовым фонолитом и др. Породы данной группы слагают многочисленные дайки в кутовой части Кандалакшского залива, на участке от мыса Пентельский до Порьей губы, а также на юге Турьего полуострова. Кроме того щелочные дайки часто секут породы мелких и крупных щелочных массивов Кольского региона. В пробе Мосеево валунов данной группы существенно больше (11 шт.), чем в пробе Кузрека (2 шт.). Это связано с их сносом с Турьего п-ва, что косвенно подтверждается присутствием в пробе Мосеево фенитизированных песчаников и гранитоидов.

10. Фойдолиты представлены уртитом, микроийолитом, мельтейгитом. Породы данной группы развиты в Хибинском и Ловозёрском массивах, в мелких щелочных массивах, а также на п-ве Турий и в трубках взрыва.

11. К гранофирам отнесены породы с характерной гранофировой текстурой, которая представляет собой микрографические срастания полевых шпатов и кварца. Данные породы известны 
на юго-западе от Хибинского массива на контакте пород имандровского лополита с вулканогенноосадочными толщами, также они встречаются в виде жил в основных интрузивах Мончегорского района [9].

12. Долериты, метагаббро-долериты состоят из клинопироксена (в изменённых разностях - амфибола) и мелких лейст плагиоклаза и имеют характерную долеритовую структуру. Они могли быть принесены из дайковых комплексов, секущих интрузии основных пород КандалакшскоКолвицкой зоны, Главного хребта или Мончегорского района. Также подобные породы встречаются в вулканогенно-осадочных толщах [8].

13. Mетаперидотиты представлены серпентинизированными и хлоритизированными ультраосновными породами. Их источником могли послужить массивы порьегубского комплекса района Порьей губы или Главного хребта и небольшие интрузии вочеламбинского комплекса, секущие вулканогенно-осадочные толщи на юго-западе и юге от Хибинского массива. Не исключено также попадание подобных пород из интрузий Мончегорского района или мелких тел алакуртинского комплекса, встречающихся на юго-востоке от оз. Колвицкое.

14. Плагиовебстерит представляет собой двупироксеновую среднезернистую породу с агрегатами мелкого плагиоклаза в промежутках между пироксенами. Источником данных пород могли послужить мелкие массивы комплекса Застейд восточнее оз. Колвицкое, массивы основных пород Мончегорского района или Кандлакшско-Колвицкой зоны.

Особенности петрографического состава абляционного тилла, рассмотренные выше, позволяют сделать вывод, что в основном ледниковый снос происходил с запада и северо-запада, на что указывает широкое распространение в пробах гнейсов, амфиболитов, гранулитов, габброидов/метагабброидов, нефелиновых сиенитов и др. Перемещение этих пород осуществлялось крупными потоками скандинавского ледника. Присутствие в пробе Мосеево фенитизированных песчаников и гранитоидов, а также разнообразных щелочных пород дайкового комплекса полуострова Турий указывает на перемещение обломочного материала с юго-запада на северо-восток. Это объясняется воздействием Беломорского потока Скандинавского ледникового щита - мощность ледника на периферии ледникового потока в пределах района работ уменьшалась, что приводило к выжиманию насыщенного дебрисом льда в северо-восточном направлении.

Авторы выражают благодарность В.Л. Ильченко и Д.С. Толстоброву за помощь в полевых работах, В.В. Борисовой и Т.В. Рундквист за консультации при определении пород.

Исследования выполнены в рамках темы НИР ГИ КНЦ РАН № 0231-2015-0010.

\section{Литература}

1. Виноградов А.Н., Виноградова Г.В. Геология и петрология умбинского комплекса интрузивных чарнокитов и гранитов // Интрузивные чарнокиты и порфировидные граниты Кольского полуострова. Апатиты, 1975. С. 3-148.

2. Геологическая карта Кольского региона / под ред. Ф.П. Митрофанова. Апатиты, 2001.

3. Государственная геологическая карта РФ масштаба 1:1000000. Балтийская серия. Геологическая карта четвертичных образований. Лист Q-(35), 36 (Апатиты) / Л.Р. Семёнова, А.Е. Рыбалко. 2010.

4. Евдокимов М.Д. Фениты Турьинского щелочного комплекса Кольского полуострова (минеральные ассоциации и геохимические особенности). Л.: Изд-во ЛГУ, 1982. 248 с.

5. Евзеров В.Я., Кошечкин Б.И. Палеогеография плейстоцена западной части Кольского полуострова. Л.: Наука, 1980. 104 с.

6. История формирования рельефа и рыхлых отложений северо-восточной части Балтийского щита / С.А. Стрелков и др. Л.: Наука, 1976. 164 с.

7. Лаврова М.А. Четвертичная геология Кольского полуострова. М.-Л.: Изд-во АН СССР, 1960.234 с.

8. Объяснительная записка к Геологической карте северо-восточной части Балтийского щита масштаба 1:500000 / А.Т. Радченко и др. Апатиты: Изд-во КНЦ РАН, 1994. 95 с.

9. Расслоенные интрузии Мончегорского рудного района: петрология, оруденение, изотопия, глубинное строение / В.Ф. Смолькин и др. Апатиты: Изд-во КНЦ РАН, 2004. Ч. 1. 177 с. 